\title{
Induction of defense in apples by sulfated and deacetylated chichá gum
}

\author{
Carlos Pinheiro Chagas de Lima1 (D), Andréia Hansen 0ster² (D), Fábio Rossi Cavalcanti ${ }^{2}$ (D), \\ Regina Célia Monteiro de Paula ${ }^{1}$ (D) and Judith Pessoa Andrade Feitosa1* \\ 'Laboratório de Polímeros - LabPol, Departamento de Química Orgânica e \\ Inorgânica - DQOI, Universidade Federal do Ceará - UFC, Fortaleza, CE, Brasil \\ ${ }^{2}$ Empresa Brasileira de Pesquisa Agropecuária - Embrapa Uva e Vinho, Bento Gonçalves, RS, Brasil \\ *judith@dqoi.ufc.br
}

\begin{abstract}
Elicitors activate the defense mechanism in plants to resist pathogens. Ulvans and glucuronans can act as elicitors, and their activity seems to be related to the sulfate groups, rhamnose and uronic acid monosaccharides. Chichá gum (CHG), which also contains rhamnose and uronic acid, was sulfated with chlorosulfonic acid/N,N-dimethylformamide and deacetylated with sodium hydroxide solution. The changes were confirmed by infrared spectroscopy. Carbon-13 NMR revealed that sulfation occurred in galactose and rhamnose units. The apples were sprayed with water (negative control), deacetylated chichá gum (DCHG), and sulfated chichá gum (SCHG). The activity of enzymes guaiacol peroxidase and polyphenol oxidases and the lignin content were compared with those under the action of a commercial elicitor, benzothiadiazole. DCHG, and especially SCHG, increased the activity of the two enzymes. Only fruits treated with SCHG showed a significant $(\mathrm{p}<0.05)$ increase in lignin content. The plant exudate can be one abundant, renewable and safe source of elicitors.
\end{abstract}

Keywords: benzothiadiazole (BTH), Sterculia striata, elicitor, polysaccharide, sulfation.

How to cite: Lima, C. P. C., Oster, A. H., Cavalcanti, F. R., Paula, R. C. M., \& Feitosa, J. P. A. (2021). Induction of defense in apples by sulfated and deacetylated chichá gum. Polímeros: Ciência e Tecnologia, 31(1), e2021010. https:// doi.org/10.1590/0104-1428.08820

\section{Introduction}

Elicitors are molecules capable of induce defense responses. Because these molecules can protect plants against pathogens, they are promising for reducing the use of agrochemicals ${ }^{[1]}$. Among the various compounds that may act as elicitors, there are the polysaccharides from seaweed ${ }^{[2,3]}$. The most promising algae-derived polysaccharides for defense induction in plant tissue are ulvans and glucuronans, which are widely available due to the abundance of green algae ${ }^{[3,4]}$.

Ulvans protected tomato plants against Alternaria solani and Xanthomonas vesicatoria ${ }^{[5]}$ and apple fruits against Penicillium expansum and Botrytis cinerea ${ }^{[2]}$. Ulvans are basically composed of rhamnose (16.8-45.0\%), sulfate groups (16.0-23.2\%), uronic acids (6.5-19\%), xylose (2.1-12.0\%), iduronic acid (1.1-9.1\%), and glucose $(0.5-6.4 \%)^{[4]}$. According El Modafar et al. $(2012)^{[6]}$ the ability of ulvans to induce plant defense may be related to the presence of rhamnose and sulfate groups. Glucuronans, to a lesser extent, and oligoglucuronans, to a greater extent, protected tomato seedlings against Fusarium oxysporum $f$. sp. Lycopersici ${ }^{[6]}$ and apples against Penicillium expansum and Botrytis cinerea ${ }^{[3]}$. As glucuronans are composed primarily of residues of glucuronic acids, and these residues may be related to the defense-inducing activity.

Three polysaccharide subunits are reportedly related to the elicitation of apples defenses: rhamnose, uronic acid, and sulfate groups. A polysaccharide extracted from the exudate of Sterculia striata, commonly known as chichá gum (CHG), has - in addition to xylose (5.6-7.7\%), galactose (19.3-23.4\%), and acetyl groups (9.6-10.7\%) - rhamnose (23.1-28.8\%), and uronic acids $(42.2-49.2 \%)^{[7,8]}$. Chemical modifications that remove acetyl groups (deacetylation) and add sulfate groups (sulfation) could make the composition of CHG more similar to that of polysaccharides from green algae, making $\mathrm{CHG}$ more interesting for apple elicitation tests. In addition, the synthesis and physiological role of sulfated polysaccharides has receiving great attention so far and is another novelty in this work.

Apples are one of the most pesticide-treated crops ${ }^{[9]}$. The 'Pink Lady' cultivar was selected as it is susceptible to diseases and thus requires high use of agrochemicals ${ }^{[10]}$. The objective of this work is to deacetylate and sulfate (for the first time) $\mathrm{CHG}$, characterize the derivatives, and evaluate the ability of these polysaccharides to enhance the protection of "Pink Lady" apples against pathogens. The results are compared with those of a widely used synthetic elicitor, benzothiadiazole (BTH). The carcinogenicity of BTH is 
classified as Category $1 \mathrm{~A}^{[11]}$, which means: "known to have carcinogenic potential for humans ${ }^{[12]}$.

\section{Materials and Methods}

\subsection{Materials}

Sterculia striata exudate was obtained from a tree located in Fortaleza-Ceará (Brazil). BTH, sodium hypochlorite, phosphate buffered saline ( $\mathrm{pH} 7.4)$, citric acid, bovine serum albumin, monolignol (guaiacol) peroxidase, guaiacol, hydrogen peroxide, pyrocathecol, acetone, thioglycolic acid, and 2-hydroxypropyl ether were supplied by Sigma-Aldrich, São Paulo, Brazil. Sodium hydroxide, $N, N$-dimethylformamide (DMF), and chlorosulfonic acid (CSA) were obtained from Vetec, Brazil. Sodium chloride, hydrochloric acid, and ethanol were purchased from Synth, São Paulo, Brazil.

\subsection{Isolation of $\mathrm{CHG}$}

The gum was isolated by the methodology of Brito et al. ${ }^{[8]}$, with adaptations. An exudate aqueous solution $(1 \% \mathrm{w} / \mathrm{v})$ was filtered through a sintered plate funnel (G1) and the $\mathrm{pH}$ was adjusted to 7.0 by adding of $1.0 \mathrm{~mol} . \mathrm{L}^{-1} \mathrm{NaOH}$. Sodium chloride (half of the exudate mass) was added. After $3 \mathrm{~h}$, the gum was precipitated in 2 volumes of ethanol and filtered through a sintered plate funnel (G4). The precipitate was washed three times with ethanol and dried in a desiccator under vacuum. The obtained sample is denoted as CHG.

\subsection{Sulfation of chichá gum}

The sulfation of $\mathrm{CHG}$ was based on the method reported by Pires et al. (2013) ${ }^{[13]}$, with several modifications. $1 \mathrm{~g}$ sample of the polysaccharide and $50 \mathrm{~mL}$ of DMF were placed in a round-bottom flask $(250 \mathrm{~mL})$. After $15 \mathrm{~h}$ under stirring, another $50 \mathrm{~mL}$ aliquot of DMF was added. In an ice bath, $6 \mathrm{~mL}$ of CSA was slowly added to the solution, and the reaction was allowed to run for $3 \mathrm{~h}$ at room temperature (around $28^{\circ} \mathrm{C}$ ). Addition of $200 \mathrm{~mL}$ of ethanol stopped the reaction. To improve the precipitation of the sulfated derivative, $0.5 \mathrm{~g}$ of $\mathrm{NaCl}$ was added. The precipitate was retained in a sintered plate funnel (G3), washed twice with ethanol, and dissolved in $200 \mathrm{~mL}$ of distilled water. The $\mathrm{pH}$ was adjusted to 7.0 with $1.0 \mathrm{~mol} . \mathrm{L}^{-1} \mathrm{NaOH}$, and the solution was dialyzed against distilled water. The sample was recovered by lyophilization, and the sulfated gum (SCHG) was obtained.

\subsection{Deacetylation of $\mathrm{CHG}$}

The procedure reported by Brito et al. (2005) ${ }^{[7]}$ was used for deacetylation of chichá gum. CHG aqueous solution $(200 \mathrm{~mL}$, $1 \% \mathrm{w} / \mathrm{v}$ ) was mixed with $200 \mathrm{~mL}$ of $1.0 \mathrm{~mol} . \mathrm{L}^{-1} \mathrm{NaOH}$ solution under stirring. After $20 \mathrm{~min}$, the mixture was neutralized using $6.0 \mathrm{~mol} . \mathrm{L}^{-1} \mathrm{HCl}$, and dialyzed for 4 days, while monitoring the conductivity. The solid obtained by lyophilization is denoted as deacetylayed chichá gum (DCHG).

\subsection{Characterization of chichá gum and its derivatives}

\subsubsection{Determination of the degree of sulfation of SCHG}

The percentage of carbon $(\% \mathrm{C})$ and sulfur $(\% \mathrm{~S})$ in the sulfated derivative was measured using Perkin Elmer
2400 Series II CHNS/O microanalyzer (Massachusetts, US). Equation 1 was used to calculate the degree of sulfation (DS):

$$
D S=(\% S / M s) /(\% C / 6 \times M c)
$$

where $\mathrm{M}_{\mathrm{s}}$ and $\mathrm{M}_{\mathrm{c}}$ are the atomic mass of sulfur and carbon, respectively.

\subsubsection{Fourier-transform infrared spectroscopy (FTIR)}

The absorption spectra of CHG, SCHG, and DCHG in the infrared region were obtained for the samples in $\mathrm{KBr}$ pellets by using a Shimadzu IRT Race100 FTIR spectrophotometer, in the range of $400-4000 \mathrm{~cm}^{-1}$.

\subsubsection{Thermal analysis (TGA, DSC)}

Samples of the gums $(10 \mathrm{mg})$ were subjected to thermogravimetric analysis on TGAQ50 equipment (TA Instruments) under synthetic air atmosphere at a heating rate of $10{ }^{\circ} \mathrm{C} \mathrm{min}{ }^{-1}$. The dehydration and total decomposition rates were identified to determine the moisture and ash content, respectively. The differential scanning calorimetry curves were obtained on Shimadzu DSC50 equipment under nitrogen atmosphere using a flow of $50 \mathrm{~mL} \mathrm{~min}^{-1}$ and $4.0 \mathrm{mg}$ of sample, in the temperature range of $27-450^{\circ} \mathrm{C}$, at a heating rate of $10{ }^{\circ} \mathrm{C} \mathrm{min}^{-1}$.

\subsubsection{Gel permeation chromatography (GPC)}

Solutions of the gums $(0.1 \% \mathrm{w} / \mathrm{v})$ in $0.1 \mathrm{~mol} \mathrm{~L}^{-1}$ sodium nitrate were prepared by magnetic stirring in a water-bath $\left(70{ }^{\circ} \mathrm{C}\right.$ ) for $12 \mathrm{~h}$, and filtered through a $0.45 \mu \mathrm{m}$ Millipore membrane. Shimadzu equipment (Kyoto, Japan) consisting of a pump (LC10AD) coupled to a refractive index detector (RID6A) was employed. A Phenomenex precolumn PolySepGFCP $(35 \mathrm{~mm} \times 7.80 \mathrm{~mm})$ and PolySepGFCP linear column $(300 \mathrm{~mm} \times 7.80 \mathrm{~mm})$ were used for the separation process. A $0.1 \mathrm{~mol} \mathrm{~L}^{-1} \mathrm{NaNO}_{3}$ solution was used as the eluent at a flow rate of $1.0 \mathrm{~mL} \mathrm{~min}{ }^{-1}$ and sample volume was $50 \mu \mathrm{L}$. The standard curve for the molar mass determination was constructed using polystyrene sulfonate standards $(\log \mathrm{M}=13.92-0.99 \mathrm{Ve})$ according to Dupont ${ }^{[14]}$.

\subsubsection{Carbon-13 nuclear magnetic resonance $\left({ }^{13} \mathrm{C}-\mathrm{NMR}\right)$}

The gums were dissolved in $\mathrm{D}_{2} \mathrm{O}$ with $1 \%$ sodium 2,2-dimethylsilapentane-5-sulfonate (DSS) for zero calibration of the chemical shift. CHG was subjected to partial acid hydrolysis to improve the spectral resolution. The spectra were obtained at $70{ }^{\circ} \mathrm{C}$ on a Bruker Avance RX500 model spectrometer (Massachusetts, US).

\subsection{Biochemical tests}

\subsubsection{Material preparation and fruit treatments}

The polysaccharides and BTH were dissolved in distilled water at a concentration of $5 \mathrm{mg} \mathrm{mL}^{-1}$ for DCHG and $\mathrm{SCHG}^{[2,3]}$ and $0.4 \mathrm{mg} \mathrm{mL}^{-1}$ for $\mathrm{BTH}^{[10]}$ (positive control, Ctrl+). 'Pink Lady' apples were harvested in Vacaria, Rio Grande do Sul state (Brazil) and the fruits were further sanitized in $2 \%(\mathrm{v} / \mathrm{v})$ sodium hypochlorite solution. Once dried, the apples were sprayed with distilled water (negative control, Ctrl-), the gums, and BTH. In a completely randomized experiment, 
three apple samples (per treatment) were taken at times of $12,24,48$, and $72 \mathrm{~h}$ after spraying (HAS) for pulp sampling. The soluble protein, extracted lignin, and enzyme activity were evaluated. For the chosen time interval, the apples were subjected to B. D. O (Biochemical Oxygen Demand) chamber conditions for $24 \mathrm{~h}$ in the dark at $25^{\circ} \mathrm{C}$.

\subsubsection{Enzyme and lignin determination}

Pulp samples were taken from apple fruits with a spudger and homogenized for $2 \mathrm{~min}$ in a mortar in 1:3 (w/v) dilution with $100 \mathrm{mmol} \mathrm{L}^{-1} \mathrm{PBS} \mathrm{pH} 7.4$ buffer containing $25 \mathrm{mmol} \mathrm{L}^{-1}$ citric acid (cooled). After gauze filtration, the fresh material was centrifuged at $12,400 \times \mathrm{g}$ for $10 \mathrm{~min}$ at $4{ }^{\circ} \mathrm{C}$. The crude extract obtained from the supernatant was used for enzymatic determinations ${ }^{[15]}$. The soluble protein $\left(\mathrm{mgP} \mathrm{mL}^{-1}\right)$ from the crude extracts was pre-determined using $0.3 \mathrm{~mol} \mathrm{~L}^{-1}$ bovine serum albumin (BSA) ${ }^{[16]}$.

To determine the enzyme activity, $100 \mu \mathrm{L}$ of crude extract (supernatant) was used as the substrate in the enzyme mixtures comprising $2.0 \mathrm{~mL}$ of a solution containing $50 \mathrm{mmol} \mathrm{L}^{-1}$ sodium acetate buffer ( $\mathrm{pH} \mathrm{6.8),}$ $20 \mathrm{mmol} \mathrm{L}^{-1}$ guaiacol and $30 \mathrm{mmol} \mathrm{L}^{-1}$ hydrogen peroxide for guaiacol peroxidase (GPX, EC 1.11.1.7). The procedure was the same for polyphenol oxidases (PPO, EC 1.10.3.1), however without hydrogen peroxide and with $30 \mathrm{mmol} \mathrm{L}^{-1}$ pyrocathecol instead of guaiacol. The activity of the two enzymes was recorded over the course of $10 \mathrm{~min}$ using a spectrophotometer. The GPX activity and PPO were read at 480 and $410 \mathrm{~nm}$, respectively ${ }^{[15]}$. The relative activity unit (UA) of both oxidases was defined as the change in the enzyme absorbance at the respective wavelengths by one milligram of soluble protein per min (UA mg.P. ${ }^{-1} \mathrm{~min}^{-1}$ ).

For the lignin determination, $0.2 \mathrm{~g}$ fresh samples of 'Pink Lady' apple pulps were powdered in a mortar with liquid nitrogen for $3 \mathrm{~min}$. The samples were incubated in $85 \%$ acetone for $48 \mathrm{~h}$. After centrifugation at $8,000 \times \mathrm{g}$ for $15 \mathrm{~min}$ at $7{ }^{\circ} \mathrm{C}$, the dried precipitate was resuspended in $5 \mathrm{~mL}$ thioglycolic acid diluted in $2 \mathrm{~mol} \mathrm{~L}^{-1}$ hydrochloric acid $(1: 10, \mathrm{v} / \mathrm{v})$. The suspensions were incubated for $4 \mathrm{~h}$ at $25^{\circ} \mathrm{C}$ and centrifuged at $8,000 \times \mathrm{g}$. The supernatant was then transferred to a $20 \mathrm{~mL}$ tube; $200 \mu \mathrm{L}$ of $10 \mathrm{~mol} \mathrm{~L}^{-1}$ hydrochloric acid was added and the mixture was incubated in an icebath for $4 \mathrm{~h}$. After centrifugation at $8.000 \times \mathrm{g}$, the pellet was homogenized in $5 \mathrm{~mL}$ of $0.5 \mathrm{~mol} \mathrm{~L}^{-1} \mathrm{NaOH}$ and the absorbance was measured at $280 \mathrm{~nm}$. Thioglycolic acid derivatives (lignin) were measured by comparison with a $10-100 \mu \mathrm{g} \mathrm{mL}^{-1}$ standard curve for 2-hydroxypropyl ether ${ }^{[17]}$.

\subsubsection{Statistical analysis}

Regarding enzyme responses, descriptive statistics and standard deviations between gum-, Bion- treatments and water-pre-treated (Ctrl-) apples were compared with vertical bars beside averages in each hour of time interval. For the lignin determinations, normality (Shapiro-Wilk), homoscedasticity (Bartlett), ANOVA and Tukey tests were run at 5\% significance with a specific $\mathrm{R}$ script ( $\mathrm{R}$ version 3.5.0 - The R Foundation, 2018).

\section{Results and Discussions}

\subsection{Characterization of chichá gum and its sulfated and deacetylated derivatives}

The isolation, sulfation, and deacetylation yields were 52,105 , and $76 \%$, respectively. A yield exceeding $100 \%$ is justified because hydrogen atoms $\left(1.0 \mathrm{~g} \mathrm{~mol}^{-1}\right)$ in the molecular structure are replaced by $\mathrm{SO}_{3} \mathrm{Na}$ groups $\left(103.1 \mathrm{~g} \mathrm{~mol}^{-1}\right)$ during the sulfation process. Other authors have observed sulfation yields above $100 \%{ }^{[18,19]}$. The percentage of sulfur and degree of sulfation achieved were $8.7 \%$ and 0.82 , respectively.

\subsubsection{Infrared absorption spectroscopy (FTIR)}

The spectra of chichá gum and its derivatives are shown in Figure 1a. The band at $3421 \mathrm{~cm}^{-1}$ is attributed to the stretching of the $\mathrm{O}-\mathrm{H}$ bonds ${ }^{[20]}$. This band was narrower for the SCHG, plausibly because for each sulfate group inserted, one O-H group is lost. For the DCHG, this band was slightly wider. The bandwidth is related to intermolecular interactions. Stronger interaction leads to a wider bandwidth ${ }^{[21]}$. The bands at 2933 and $1378 \mathrm{~cm}^{-1}$ were attributed to $\mathrm{C}-\mathrm{H}$ $\left(\mathrm{CH}_{3}\right)$ stretching and deformation, respectively ${ }^{[21,22]}$. These two bands were similar for $\mathrm{CHG}$ and SCHG because the sulfation process does not change the number of $\mathrm{C}-\mathrm{H}$ bonds in the macromolecule. For DCHG, the band at $2933 \mathrm{~cm}^{-1}$ became narrower and that at $1378 \mathrm{~cm}^{-1}$ practically disappeared due to loss of the acetyl groups.

The bands at 1148, 1066, and $1042 \mathrm{~cm}^{-1}$ (fingerprint region) correspond to the stretching vibrations of various $\mathrm{C}-\mathrm{O}-\mathrm{C}$ bonds present in carbohydrates in general $^{[22]}$. The band at $1730 \mathrm{~cm}^{-1}$, which was absent in the FTIR profile of
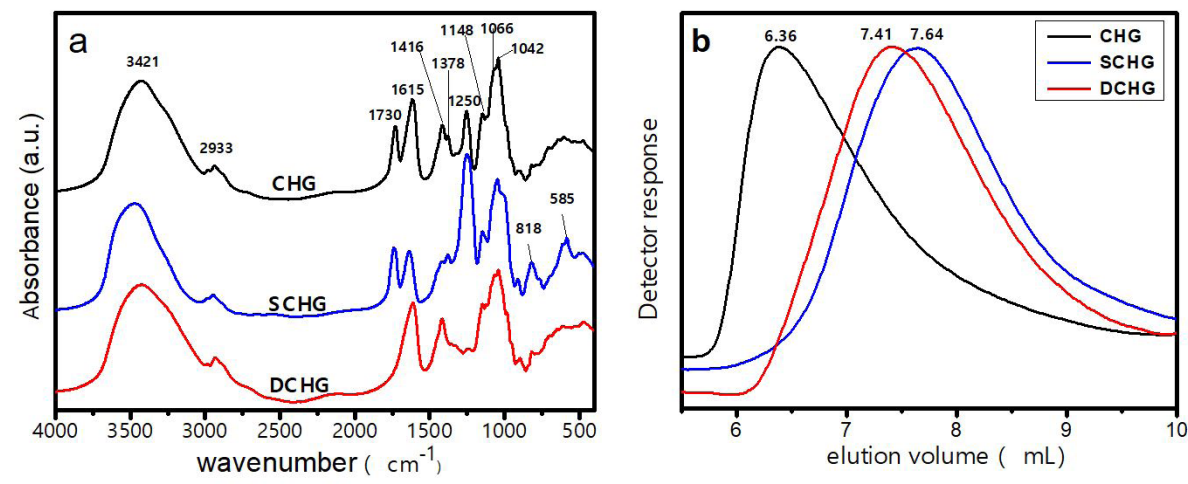

Figure 1. (a) FTIR and b) GPC profiles of CHG and its sulfated and deacetylated derivatives. 
$\mathrm{DCHG}$, and present in that of $\mathrm{CHG}$ and $\mathrm{SCHG}$, is assigned to $\mathrm{C}=\mathrm{O}$ from the acetyl groups. Intensification of the band at $1250 \mathrm{~cm}^{-1}$ was observed for SCHG. This absorbance is assigned to the $\mathrm{S}=\mathrm{O}$ bonds of sulfate groups, and also to the acetyl group ${ }^{[21,23]}$. For this reason, this band is not present in the spectrum of DCHG. The bands appearing at 818 and $584 \mathrm{~cm}^{-1}$ are due to the asymmetric and symmetric stretching of the $\mathrm{O}=\mathrm{S}=\mathrm{O}$ bonds of the sulfate group, respectively ${ }^{[24]}$.

\subsubsection{Gel permeation chromatography (GPC)}

Figure $1 \mathrm{~b}$ shows that the modified polysaccharides required a larger volume of eluent for detection. This suggests that sulfation and deacetylation degrade the polysaccharide. The average molar masses $\left(M_{W}\right.$ and $\left.M_{N}\right)$ of $\mathrm{CHG}$ are $15.1 \times 10^{6}$ and $0.42 \times 10^{6} \mathrm{~g} \mathrm{~mol}^{-1}$, respectively. Average molar masses of the same order of magnitude were reported for a similar polysaccharide (karaya gum), i.e., $M_{W}=16.1 \times 10^{6}$ and $M_{N}=1.1 \times 10^{6} \mathrm{~g} \mathrm{~mol}^{-1}[25]$. After deacetylation of $\mathrm{CHG}$, the $M_{W}$ decreased to $4.8 \times 10^{6} \mathrm{~g} \mathrm{~mol}^{-1}$. A similar value was observed for deacetylated karaya gum, i.e., $1.8 \times 10^{6} \mathrm{~g} \mathrm{~mol}^{-1}[22]$. Opposite results, i.e., an increase in the $M_{W}$ after deacetylation of karaya gum $\left(2-5 \times 10^{6}\right.$ to $12-16 \times 10^{6}$ g. mol $\left.{ }^{-1}\right)$ was reported by Le Cerf, Irinei, \& Muller (1990 ${ }^{[26]}$. However, the authors explained that deacetylation enables water solubilization of high- $M_{W}$ polymeric chains at high $\mathrm{pH}$, while solubilization of the original gum without adjusting the $\mathrm{pH}$ was only partial, where only fractions of lower $M_{W}$ were soluble. The molar mass of SCHG declined to $3.8 \times 10^{6} \mathrm{~g} \mathrm{~mol}^{-1}$ (around four times), but no sulfation studies were found for karaya or CHG to compare.

\subsubsection{Thermal analysis (TGA, DSC)}

SCHG and DCHG were less thermally stable than the $\mathrm{CHG}$ (Figure 2a). Degradation began at a lower temperature for SCHG and DCHG $\left(217.5 \pm 0.5^{\circ} \mathrm{C}\right)$ than for $\mathrm{CHG}\left(236^{\circ} \mathrm{C}\right)$. The moisture content of $\mathrm{CHG}$ is close to that of $\mathrm{DCHG}$ $(18.1 \pm 0.1 \%)$ and is greater than that of SCHG (15.7\%). These values are in the moisture content range of karaya gum: $13 \%{ }^{[27]}$ and $20 \%{ }^{[22]}$. The moisture content of DCHG was higher than the values reported for deacetylated karaya gum, i.e., $13-15 \%{ }^{[22]}$. More residue was generated at $800{ }^{\circ} \mathrm{C}$ for SCHG (21.8\%) than for CHG (9.2\%) and DCHG (4.6\%). The increase in the amount of residue after sulfation is due to the presence of the sodium $\left(\mathrm{Na}^{+}\right)$counter ion of the sulfate groups ${ }^{[13]}$. The lower value for DCHG compared with that of CHG may be due to unintended purification of the gum during deacetylation.

Figure $2 \mathrm{~b}$ shows the DSC curves of CHG and its derivatives. Two events were observed for all polysaccharides. The first (endothermic) is related to water loss, and the second (exothermic) to thermal decomposition. The enthalpy of water loss followed the order: DCHG $\left(677 \mathrm{~J} \mathrm{~g}^{-1}\right)>\mathrm{CHG}$ $\left(575 \mathrm{~J} \mathrm{~g}^{-1}\right)>\operatorname{SCHG}\left(345 \mathrm{~J} \mathrm{~g}^{-1}\right)$. The order was maintained even when the difference in the moisture content of the samples was taken into account. The maximum degradation occurred at $280 \pm 2{ }^{\circ} \mathrm{C}$ for the $\mathrm{CHG}$ and $\mathrm{DCHG}$, and at $236^{\circ} \mathrm{C}$ for the sulfated polysaccharide. The enthalpy of degradation was lowest for SCHG $\left(117 \mathrm{~J} \mathrm{~g}^{-1}\right)$, whereas the values for DCHG and $\mathrm{CHG}$ were close, i.e., 156 and $163 \mathrm{~J} \mathrm{~g}^{-1}$, respectively. Sulfation apparently weakened the chemical bonds of the polysaccharides.

\subsubsection{Carbon-13 nuclear magnetic resonance $\left({ }^{13} \mathrm{C}-\mathrm{NMR}\right)$}

Figure 3 shows the ${ }^{13} \mathrm{C}-\mathrm{NMR}$ spectrum of $\mathrm{SCHG}$. The signal/noise ratio is somewhat poor; nevertheless, important information can be derived. The spectra of CHG and DCHG presented in Supplementary Material Figure S1 are similar to those reported by Brito et al. ${ }^{[8]}$. The absence of the band at $23.31 \mathrm{ppm}$ ppm in the DCHG spectrum reaffirms the success of deacetylation and corroborates the FTIR results. The spectra of CHG and DCHG show signals at $60.46,61.70,61.21$, and $61.63 \mathrm{ppm}$. These peaks are absent in the profile of SCHG, and can be attributed to carbon 6 of the galactose residues ${ }^{[28,29]}$. Another possibility is that the peaks may be attributed to the 4-O-methyl glucuronic or 4-O-methyl- galacturonic group, but this polysaccharide does not possess these residues ${ }^{[8]}$. The two new peaks that emerged in the ${ }^{13} \mathrm{C}-\mathrm{NMR}$ spectrum of $\mathrm{SCHG}$ at 68.86 and $70.07 \mathrm{ppm}$, attributed to the sulfated carbon 6 of the galactose residues, shifted by $\sim 6 \mathrm{ppm}$ to lower-field. The peak at $23.31 \mathrm{ppm}$ in the ${ }^{13} \mathrm{C}$-NMR spectrum of SCHG is due not only to methyl acetyl groups ${ }^{[8,25]}$, but also to the methyl groups of sulfated rhamnose, and was shifted by $\sim 4 \mathrm{ppm}$. The ${ }^{13} \mathrm{C}$-NMR spectra of sulfated materials are known to be more complicated because the sulfate groups withdraw electrons from the carbons to which they bond, shifting the signals of these carbons to lower-field, and donate electrons
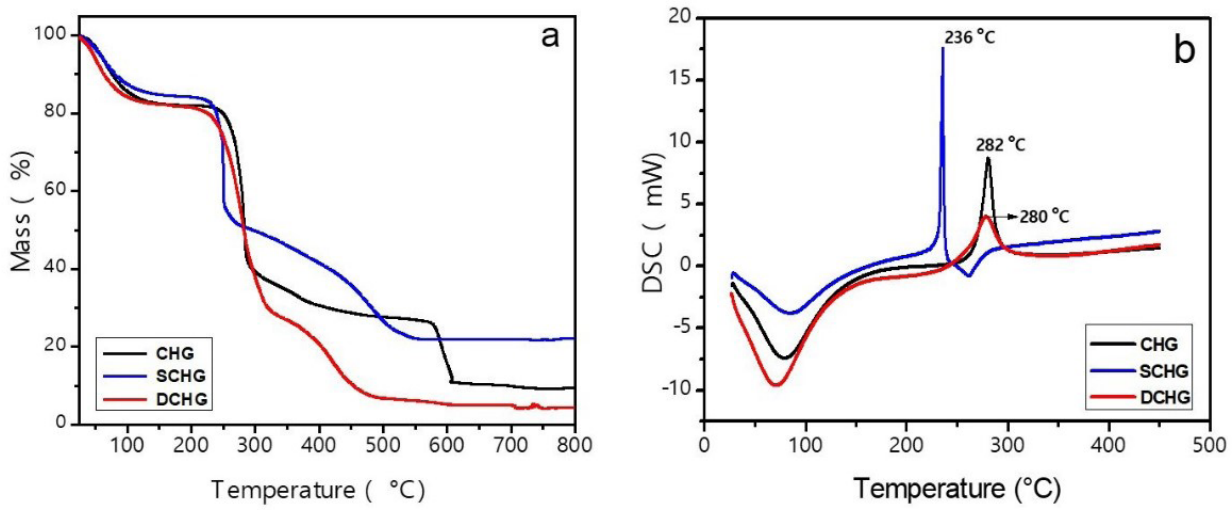

Figure 2. (a) TGA (in air) and (b) DSC (in $\mathrm{N}_{2}$ ) curves of $\mathrm{CHG}$ its derivatives. 


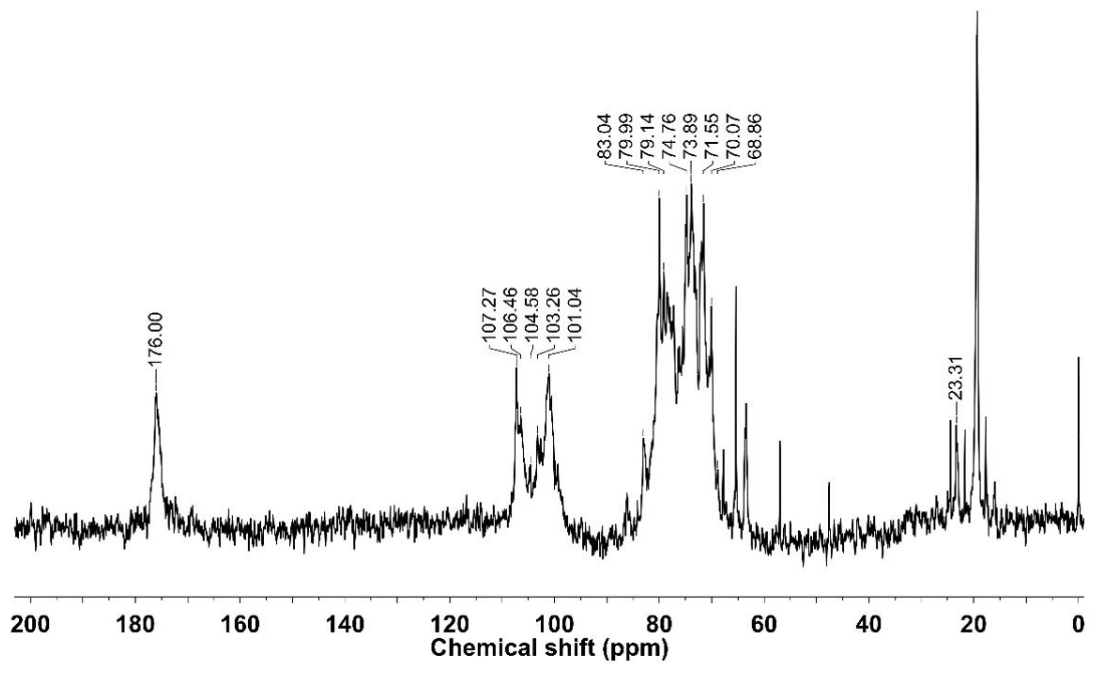

Figure 3. ${ }^{13} \mathrm{C}-\mathrm{NMR}$ spectrum of SCHG.
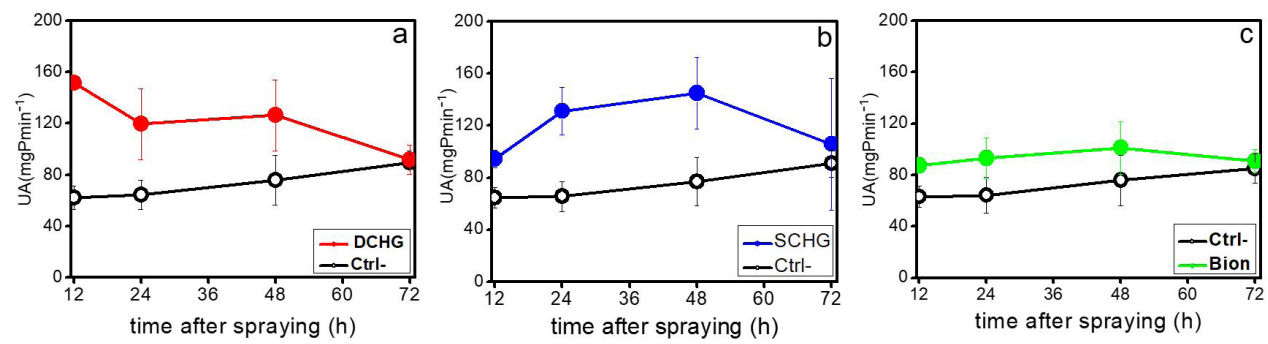

Figure 4. GPX activity in Pink Lady apples after spraying with distilled water (control, Ctrl), and DCHG (a), SCHG (b), and BTH (c).
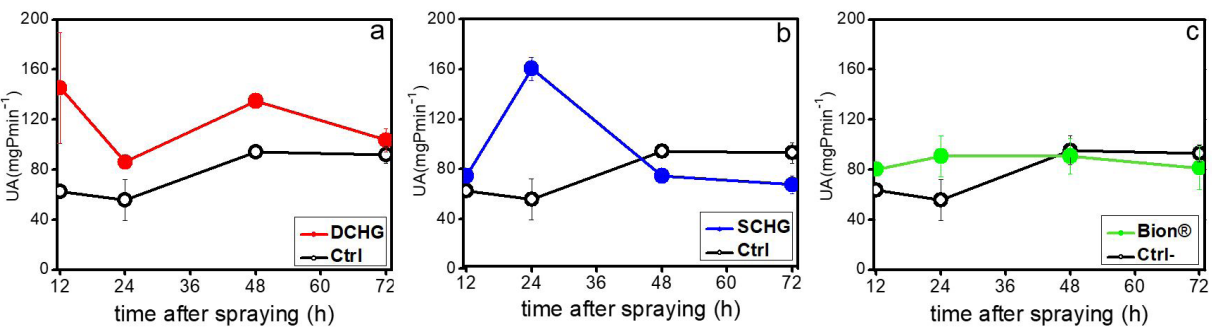

Figure 5. PPO activity in Pink Lady apples after spraying with distilled water (control, Ctrl), and DCHG (a), SCHG (b), and BTH (c).

to neighboring carbons, shifting these carbon signals to higher-field ${ }^{[29,30]}$.

\subsection{Enzymes and lignins related to plant defense in 'Pink Lady' apples exposed to elicitors}

The activity of the guaiacol peroxidase (GPX) and polyphenoloxidase (PPO) enzymes was recorded for gumtreated and water-treated (Ctrl-) 'Pink Lady' apple pulps. The BTH was adopted as a positive control to test the elicitor properties of the gums. The GPX activity increased significantly $(\mathrm{p}<0.05)$ with DCHG and SCHG at $12-48 \mathrm{~h}$ (Figure $4 \mathrm{a}$ and $\mathrm{b}$ ). BTH $\left(0.4 \mathrm{mg} \mathrm{mL}^{-1}\right)$ induced increase in the GPX activity at $12 \mathrm{~h}$, while there was no significant increase $(p>0.05)$ at the other times. GPX plays an essential role in lignin biosynthesis in plant tissues as these enzymes catalyze the cross-linking of phenylpropanoid route monomers (coniferyl, sinapyl, and $p$-coumaryl alcohols) and their coupling in the subunits of heterogeneous polyphenols. Lignin is associated with the induction of plant defense as it strengthens the cell walls, making it difficult for pathogens to enter ${ }^{[31,32]}$.

The activity of PPO in apple pulp increased $(\mathrm{p}<0.05)$ in the interval 12-48 $\mathrm{h}$ exposure to DCHG (Figure $5 \mathrm{~b}$ ), as reported for GPX. However, in apples exposed to SCHG and $\mathrm{BTH}$, a more transient $\mathrm{PPO}$ response was triggered. PPO activity peaked for $24 \mathrm{~h}$ for both, but much less intense for apples treated with Bion. At 48 and 72 h, PPO activity was less than to control for fruits treated with SCHG. There are few specific studies to reveal details of the post-harvest enzyme responses in apples. What can be factually inferred is that SCHG gum apparently could promote greater GPX responses at the expense of $\mathrm{PPO}$, and this seems to indicate 


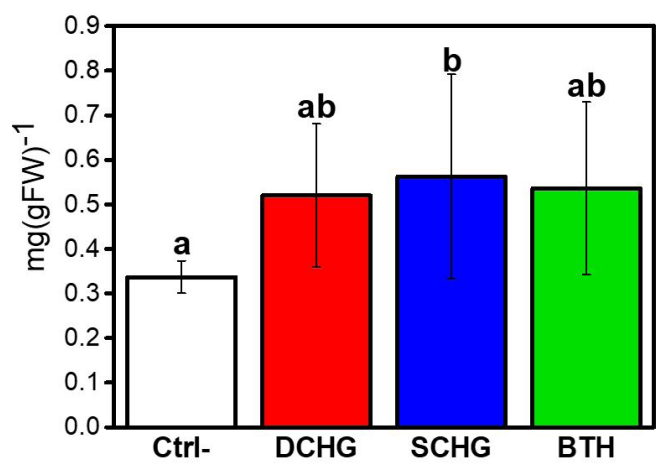

Figure 6. Lignin content (TGA derivatives, $\mathrm{mg} \mathrm{g}^{-1} \mathrm{FW}$ ) extracted from apple (cv. Pink Lady) pulps $72 \mathrm{~h}$ after spraying with elicitors. The control (Ctrl-) apples were sprayed with distilled water. Same letters indicate that the values did not differ significantly according to Tukey's test $(\mathrm{p}>0.05)$.

that GPX may have compensated PPO in the enhanced polymerization of the lignin monomers observed in SCHG treated apples. PPOs are also considered enzymes that are markers of the resistance of plants against pathogens. These enzymes oxidize phenolic compounds to toxic quinones that can act against invading pathogens ${ }^{[3]}$ and are key enzymes for the synthesis of lignin ${ }^{[33]}$.

Because the two enzymes analyzed are involved in the synthesis of lignin, the content of lignin in the fruits was quantified $72 \mathrm{~h}$ after treatment (Figure 6). As expected, due to the increase in the activity of GPX and PPO, the fruits treated with DCHG, SCHG, and BTH presented lignin levels numerically higher than that of the control. However, only the fruits treated with SCHG showed a significant $(p<0.05)$ increase in the lignin content. The lignin content of the fruits treated with DCHG and BTH was statistically similar to that of the control $(p>0.05)$. The weak induction of defense compounds (GPX, PPO and lignin) of BTH in "Pink Lady" apples can be explained by the reported low performance of BTH in this cultivar. Marolleau et al. ${ }^{[10]}$ treated Elstar, Fuji, Gala, Golden, and "Pink Lady" apple cultivars with BTH, and reported that the "Pink Lady" cultivar had the lowest level of defense induction. The results suggest 'de novo' lignin synthesis triggered by the gums, mainly SCHG, in "Pink Lady" apples. The gum that induced the strongest defense response is the one that simultaneously possesses the three residues suggested by the literature as responsible for the induction of defense compounds: rhamnose, uronic acid, and sulfate groups. This work reaffirms the importance of these residues and suggests that plant exudate polysaccharides should be further explored, as they may be a promising source of defense-inducing compounds in plants.

\section{Conclusions}

The polysaccharide from Sterculia striata (chichá gum, $\mathrm{CHG}$ ) was deacetylated (DCHG) and, for the first time, sulfated (SCHG). The derivatives were less thermally stable and the average molar mass was lower than that of the original gum. Sulfation occurred at carbon 6 of the galactose and rhamnose residues. Both derivatives of $\mathrm{CHG}$ have the ability to induce increased defense-related enzyme activity in "Pink Lady" apples. The amount of lignin extracted from the apples was greater than the control only for fruits sprayed with SCHG. The best defense induction was achieved with the polysaccharide (SCHG) that contained the three subunits associated with plant defense: rhamnose, uronic acid, and sulfate groups. This study demonstrates that plant exudate can be an abundant, renewable and safety source of elicitors.

\section{Acknowledgements}

This work was supported by the Coordination Foundation for the Improvement of Higher Education Personnel (CAPES-Brazil), CNPq, the Cearense Foundation for Research Support (FUNCAP-CE-Brazil), INOMAT, and the Brazilian Agricultural Research Corporation (EmbrapaBrazil).

\section{References}

1. Iriti, M., \& Vitalini, S. (2021). Plant immunity and crop yield: a sustainable approach in agri-food systems. Vaccines, 9(2), 1-3. http://dx.doi.org/10.3390/vaccines9020121. PMid:33546315.

2. Abouraïcha, E., El Alaoui-Talibi, Z., El Boutachfaiti, R., Petit, E., Courtois, B., Courtois, J., \& El Modafar, C. (2015). Induction of natural defense and protection against Penicillium expansum and Botrytis cinerea in apple fruit in response to bioelicitors isolated from green algae. Scientia Horticulturae, 181, 121-128. http://dx.doi.org/10.1016/j.scienta.2014.11.002.

3. Abouraïcha, E. F., El Alaoui-Talibi, Z., Tadlaoui-Ouafi, A., El Boutachfaiti, R., Petit, E., Douira, A., Courtois, B., Courtois, J., \& El Modafar, C. (2017). Glucuronan and oligoglucuronans isolated from green algae activate natural defense responses in apple fruit and reduce postharvest blue and gray mold decay. Journal of Applied Phycology, 29(1), 471-480. http://dx.doi. org/10.1007/s10811-016-0926-0.

4. Stadnik, M. J., \& Freitas, M. B. (2014). Algal polysaccharides as source of plant resistance inducers. Tropical Plant Pathology, 39(2), 111-118. http://dx.doi.org/10.1590/S198256762014000200001.

5. Ramkissoon, A., Ramsubhag, A., \& Jayaraman, J. (2017). Phytoelicitor activity of three Caribbean seaweed species on suppression of pathogenic infections in tomato plants. Journal of Applied Phycology, 29(6), 3235-3244. http://dx.doi. org/10.1007/s10811-017-1160-0.

6. El Modafar, C., Elgadda, M., El Boutachfaiti, R., Abouraicha, E., Zehhara, N., \& Petit, E. (2012). Induction of natural defence accompanied by salicylic acid dependant systemic acquired resistance in tomato seedlings in response to bioelicitors isolated from green algae. Scientia Horticulturae, 138, 55-63. http://dx.doi.org/10.1016/j.scienta.2012.02.011.

7. Brito, A. C. F., Sierakowski, M. R., Reicher, F., Feitosa, J. P. A., \& Paula, R. C. M. (2005). Dynamic rheological study of Sterculia striata and karaya polysaccharides in aqueous solution. Food Hydrocolloids, 19(5), 861-867. http://dx.doi. org/10.1016/j.foodhyd.2004.10.035.

8. Brito, A. C. F., Silva, D. A., Paula, R. C. M., \& Feitosa, J. P. A. (2004). Sterculia striata exudate polysaccharide: characterization, rheological properties and comparison with Sterculia urens (karaya) polysaccharide. Polymer International, 53(8), 10251032. http://dx.doi.org/10.1002/pi.1468.

9. Tzatzarakis, M., Kokkinakis, M., Renieri, E., Goumenou, M., Kavvalakis, M., Vakonaki, E., Chatzinikolaou, A., Stivaktakis, P., Tsakiris, I., Rizos, A., \& Tsatsakis, A. (2020). Multiresidue analysis of insecticides and fungicides in apples from the Greek market. Applying an alternative approach for risk assessment. 
Food and Chemical Toxicology, 140, 111262. http://dx.doi. org/10.1016/j.fct.2020.111262. PMid:32198030.

10. Marolleau, B., Gaucher, M., Heintz, C., Degrave, A., Warneys, R., Orain, G., Lemarquand, A., \& Brisset, M. N. (2017). When a plant resistance inducer leaves the lab for the field: integrating ASM into routine apple protection practices. Frontiers of Plant Science, 8, 1938. http://dx.doi.org/10.3389/fpls.2017.01938. PMid:29255473.

11. SYNGENTA. (2015). Material safety data sheet (MSDS) Byon ${ }^{\circledR}$, Syngenta, 4/16/2015. Retrieved in 2020, October 5, from https://assets.greenbook.net/M114161.pdf

12. McGregor, D., Boobis, A., Binaglia, M., Botham, P., Hoffstadt, L., Hubbard, S., Petry, T., Riley, A., Schwartz, D., \& Hennes, C. (2010). Guidance for the classification of carcinogens under the Globally Harmonised System of Classification and Labelling of Chemicals (GHS). Critical Reviews in Toxicology, 40(3), 245-285. http://dx.doi.org/10.3109/10408440903384717. PMid:20014893.

13. Pires, N. R., Cunha, P. L. R., Maciel, J. S., Angelim, A. L., Melo, V. M. M., Paula, R. C. M., \& Feitosa, J. P. A. (2013). Sulfated chitosan as tear substitute with no antimicrobial activity. Carbohydrate Polymers, 91(1), 92-99. http://dx.doi. org/10.1016/j.carbpol.2012.08.011. PMid:23044109.

14. Dupont, A.-L. (2002). Study of the degradation of gelatin in paper upon aging using aqueous size-exclusion chromatography. Journal of Chromatography. A, $950(1-2), 113-124$. http://dx.doi. org/10.1016/S0021-9673(02)00010-9. PMid:11990984.

15. Cavalcanti, F. R., Resende, M. L. V., Carvalho, C. P. S., Silveira, J. A. G., \& Oliveira, J. T. A. (2007). An aqueous suspension of Crinipellis perniciosa mycelium activates tomato defence responses against Xanthomonas vesicatoria. Crop Protection (Guildford, Surrey), 27(5), 729-738. http://dx.doi.org/10.1016/j. cropro.2006.06.012.

16. Bradford, M. M. (1976). A rapid and sensitive method for the quantitation of microgram quantities of protein utilizing the principle of protein-dye binding. Analytical Biochemistry, 72(12), 248-254. http://dx.doi.org/10.1016/0003-2697(76)90527-3. PMid:942051.

17. Monties, B. (1989). Lignins. In P. M. Dey, \& J. B. Harborne (Eds.), Methods in plant biochemistry (Vol. 1, pp. 113-158). New York: Academic Press. https://doi.org/10.1016/B978-012-461011-8.50010-X

18. Xing, R., Liu, S., Yu, H., Guo, Z., Li, Z., \& Li, P. (2005). Preparation of high molecular weight and high sulfate content chitosans and their potential antioxidant activity in vitro. Carbohydrate Polymers, 61(2), 148-154. http://dx.doi. org/10.1016/j.carbpol.2005.04.007.

19. Vikhoreva, G., Bannikova, G., Stolbushkina, P., Panov, A., Drozd, N., Makarov, V., Varlamov, V., \& Galbraikh, L. (2005). Preparation and anticoagulant activity of a low-molecularweight sulfated chitosan. Carbohydrate Polymers, 62(4), 327-332. http://dx.doi.org/10.1016/j.carbpol.2005.05.022.

20. Gangapuram, B. R., Bandi, R., Dadigala, R., Kotu, G. M., \& Guttena, V. (2017). Facile green synthesis of gold nanoparticles with carboxymethyl gum karaya, selective and sensitive colorimetric detection of copper (II) ions. Journal of Cluster Science, 28(5), 2873-2890. http://dx.doi.org/10.1007/s10876017-1264-3.

21. Patra, N., Vojtová, L., \& Martinová, L. (2015). Deacetylation induced changes in thermal properties of Sterculia urens gum. Journal of Thermal Analysis and Calorimetry, 122(1), 235-240. http://dx.doi.org/10.1007/s10973-015-4680-3.
22. Padil, V. V. T., Senan, C., \& Černík, M. (2015). Dodecenylsuccinic anhydride derivatives of gum karaya (Sterculia urens): Preparation, characterization, and their antibacterial properties. Journal of Agricultural and Food Chemistry, 63(14), 3757-3765. http:// dx.doi.org/10.1021/jf505783e. PMid:25797306.

23. Salehi, P., Dashti, Y., Tajabadi, F. M., Safidkon, F., \& Rabei, $R$ (2011). Structural and compositional characteristics of a sulfated galactan from the red alga Gracilaria psispérsica. Carbohydrate Polymers, 83(4), 1570-1574. http://dx.doi. org/10.1016/j.carbpol.2010.10.017.

24. Cakić, M., Nikolić, G., Ilić, L., \& Stanković, S. (2005). Synthesis and FTIR characterization of same dextran sulphates. Chemical Industry \& Chemical Engineering Quarterly, 1(2), 74-78. http://dx.doi.org/10.2298/CICEQ0502074C.

25. Postulkova, H., Chamradova, I., Pavlinak, D., Humpa, O., Jancar, J., \& Vojtova, L. (2017). Study of effects and conditions on the solubility of natural polysaccharide gum karaya. Food Hydrocolloids, 67, 148-156. http://dx.doi.org/10.1016/j. foodhyd.2017.01.011.

26. Le Cerf, D. L., Irinei, F., \& Muller, G. (1990). Solution properties of gum exudates from Sterculia urens (karaya Gum). Carbohydrate Polymers, 13(4), 375-386. http://dx.doi. org/10.1016/0144-8617(90)90037-S.

27. Singh, B., Sharma, V., \& Pal, L. (2011). Formation of Sterculia polysaccharide networks by gamma rays induced graft copolymerization for biomedical applications. Carbohydrate Polymers, 86(3), 1371-1380. http://dx.doi.org/10.1016/j. carbpol.2011.06.041.

28. Singh, B., \& Singh, B. (2017). Influence of graphene-oxide nanosheets impregnation on properties of Sterculia gumpolyacrylamide hydrogel formed by radiation induced polymerization. International Journal of Biological Macromolecules, 99, 699-712. http://dx.doi.org/10.1016/j.ijbiomac.2017.03.037. PMid:28284934.

29. Wang, J., Guo, H., Zhang, J., Wang, X., Zhao, B., Yao, J., \& Wang, Y. (2010). Sulfated modification, characterization and structure-antioxidant relationships of Artemisia sphaerocephala polysaccharides. Carbohydrate Polymers, 81(4), 897-905. http://dx.doi.org/10.1016/j.carbpol.2010.04.002.

30. Yang, X. B., Gao, X. D., Han, F., \& Tan, R. X. (2005). Sulfation of a polysaccharide produced by a marine filamentous fungus Phoma herbarum YS4108 alters its antioxidant properties in vitro. Biochimica et Biophysica Acta, 1725(1), 120-127. http:// dx.doi.org/10.1016/j.bbagen.2005.06.013. PMid:16054758.

31. Lee, M.-H., Jeon, H. S., Kim, S. H., Chung, J. H., Roppolo, D., Lee, H.-J., Cho, H. J., Tobimatsu, Y., Ralph, J., \& Park, O. K. (2019). Lignin-based barrier restricts pathogens to the infection site and confers resistance in plants. The EMBO Journal, 38(23), e101948. http://dx.doi.org/10.15252/embj.2019101948. PMid:31559647.

32. Passardi, F., Cosio, C., Penel, C., \& Dunand, C. (2005). Peroxidases have more functions than a Swiss army knife. Plant Cell Reports, 24(5), 255-265. http://dx.doi.org/10.1007/ s00299-005-0972-6. PMid:15856234.

33. Lu, Y.-C., Lu, Y., \& Fan, X. (2020). Structure and Characteristics of Lignin. In S. Sharma \& A. Kumar. Lignin biosynthesis and transformation for industrial applications (pp. 31-32). Switzerland: Springer. http://dx.doi.org/10.1007/978-3-03040663-9_2 


\section{Supplementary Material}

Supplementary material accompanies this paper.

Table S1: Molar mass of crude (GCH), sulfated (SCHG) and deacetylated (DCHG) chichá gum.

Figure S1: Carbon-13 nuclear magnetic resonance spectra of crude (CHG) and deacetylated (DCHG) chichá gum.

This material is available as part of the online article from http://www.scielo.br/po 